\title{
Feeding preference of Apostichopus japonicus: comparing carbon stable isotope analysis and carbon budget approach
}

\author{
Xiaoyue Song ${ }^{1,2,3, *}$, Chenggang Lin ${ }^{1,2, *}$, Yi Zhou ${ }^{1,2, * *}$, Xianfeng Wang ${ }^{1}$, \\ Ruiting $\mathrm{Gu}^{1,2,3}$, Shaochun $\mathrm{Xu}^{1,2,3}$, Qiang $\mathrm{Xu}^{4}$, Kang $\mathrm{Chen}^{1}$, Hongsheng Yang ${ }^{1,2, * *}$ \\ ${ }^{1}$ CAS Key Laboratory of Marine Ecology and Environmental Sciences, Institute of Oceanology, \\ Chinese Academy of Sciences, Qingdao 266071, PR China \\ ${ }^{2}$ Laboratory for Marine Ecology and Environmental Science, \\ Qingdao National Laboratory for Marine Science and Technology, Qingdao 266071, PR China \\ ${ }^{3}$ University of Chinese Academy of Sciences, Beijing 100049, PR China \\ ${ }^{4}$ State Key Laboratory of Marine Resource Utilization in South China Sea, Hainan University, 58th Renmin Road, \\ Haikou 570228, PR China
}

\begin{abstract}
Research into the feeding preferences of the sea cucumber Apostichopus japonicus is essential for its aquaculture. We adopted both carbon budget and stable isotope analysis approaches to determine the feeding preference of this species. Powdered Chaetomorpha linum, Zostera marina detritus, and muddy sediment mixed at 5 dry weight ratios (40:0:60, 30:10:60, 20:20:60, 10:30:60, and 0:40:60; diets 1,2,3,4, and 5, respectively) were fed to juvenile sea cucumbers (mean body weight: $10.45 \mathrm{~g}$ ) for 2 mo. Carbon budget analysis revealed that, based on carbon specific growth rate $\left(\% \mathrm{~d}^{-1}\right)$ and food carbon conversion efficiency $(\%)$, the experimental treatments could be divided into 2 groups, diets 1-3 and diets 4-5. Carbon contributions of the 3 ingredients based on the stable isotope analysis suggested that $C$. linum and $Z$. marina were the main carbon sources for $A$. japonicus in the 5 treatments, and $C$. linum was a better food source than $Z$. marina. In addition, a new potential index, i.e. the ratio of carbon contribution to composition $\left(R_{\mathrm{C}_{-} \text {con:C_com }}\right)$, was constructed to assess the feeding preferences of A. japonicus; according to this ratio, the preferences for the 3 diet ingredients were: muddy sediment $>C$. linum $>Z$. marina in the 5 treatments. Compared to the carbon budget method, carbon isotope analysis could distinguish the feeding preferences of $A$. japonicus for the diet ingredients in each treatment and had the advantage of being less labor intensive; thus it was considered to be a better approach for measuring the feeding preference of $A$. japonicus.
\end{abstract}

KEY WORDS: Sea cucumber $\cdot$ Chaetomorpha linum $\cdot$ Zostera marina $\cdot$ New index $\cdot$ Ratio of carbon contribution to composition

\section{INTRODUCTION}

Due to its economic and nutritional value, the sea cucumber Apostichopus japonicus has become a highly valuable fishery and aquaculture species in East Asia (Sui 1988, Liao 1997, Chen 2004, Yang et al. 2015). To meet the food demand of pond and indus-

*These authors contributed equally to this work

**Corresponding authors: yizhou@qdio.ac.cn; hshyang@ qdio.ac.cn

$\S_{\text {Corrections }}$ were made after publication. For details see www.int-res.com/abstracts/aei/v10/c_p243-253/

This corrected version: June 19, 2018 trial cultures, sea cucumbers are supplemented with artificial diets. Various ingredients are usable to produce artificial diets of this species, including powdered macroalgae, seagrass, corn, hydrolyzed soybean, dried bivalve feces, and coastal muddy sediment (Zhou et al. 2006, Guo et al. 2011, GamboaDelgado et al. 2013, Yu et al. 2014, Song et al. 2017).

(C) The authors 2018. Open Access under Creative Commons by Attribution Licence. Use, distribution and reproduction are unrestricted. Authors and original publication must be credited. 
According to previous research (Sun et al. 2004, Seo \& Lee 2011, Bai et al. 2016), diets containing 16-21\% protein and little fiber are beneficial for the growth of A. japonicus. Like many animals, sea cucumbers prefer food with higher nutritional value. During A. japonicus culture practice, farmers are often confronted with the problem of having to select among various diet ingredients. Thus, research into the feeding preference of $A$. japonicus fed different diet ingredients is essential for developing nutritionally and economically optimum diets.

Two main approaches can be adopted to evaluate and compare the feeding preferences of aquatic animals for different ingredients. The traditional approach has been to determine food budget parameters, such as ingestion rate, apparent digestibility ratio, food conversion efficiency, and specific growth rate (Yuan et al. 2006, Zhou et al. 2006, Chen et al. 2011, Orozco et al. 2014, Güroy et al. 2013). These parameters may quantitatively reflect the feeding preferences of aquatic animals from different aspects. For instance, the ingestion rate and apparent digestibility ratio focus on the food intake process; the specific growth rate measures growth performance; and the food conversion efficiency reflects both ingestion and growth processes. Over recent decades, stable isotope analysis (SIA) has increasingly been adopted to evaluate the relative contributions of several components in a mixture for ecological and geochemical research, such as assessing the contribution ratios of different food sources to various consumers (Vogel \& Van Der Merwe 1977, Boutton et al. 1978, Kelly 2000, Phillips \& Koch 2002, Newsome et al. 2011, Li et al. 2013). Similar studies have been conducted on A. japonicus, in which 2 ingredients were usually mixed together, and the relative contributions of these ingredients to experimental animals were regarded to represent the feeding preferences of sea cucumbers (Gao et al. 2011, Sun et al. 2012, 2013, Yokoyama 2013, Xia et al. 2015, 2017, Yu et al. 2015). Because the factors influencing SIA results involve both ingestion and growth processes, the comparison between SIA results and food conversion efficiency should be particularly interesting.

Either of these 2 aforementioned approaches is usually chosen for studies on the feeding preferences of A. japonicus. However, to our knowledge, no previous sea cucumber feeding preference study has compared the mass budget and stable isotopic approaches within the same experiment to determine the more suitable approach to address this issue. Furthermore, due to the conservative fractionation $(0-1 \%)$ of carbon stable isotopes between consumers and their diets, the carbon stable isotope value $\left(\delta^{13} \mathrm{C}\right)$ is commonly ap- plied to trace the food sources of consumers (Peterson \& Fry 1987, Hobson \& Welch 1992, McCutchan et al. 2003). Theoretically, SIA of both carbon and nitrogen elements would improve analysis efficiency; however, in this study, we only considered $\delta^{13} \mathrm{C}$.

The stable isotope mixing model is usually adopted to deal with food source contribution problems. In this model, $\delta^{13} \mathrm{C}$ values are used to calculate the carbon contributing proportions (C_con; \%) of diet sources to consumers, and combined with carbon contents to derive the mass contributing proportions of sources. However, when calculating the mass contributing proportions based on C_con, an important assumption is usually made in this model: the equivalent absorption rates of all carbon sources (Phillips \& Koch 2002); however, this assumption is probably invalid due to biochemical differences among various food sources (Song et al. 2017). Thus, we only used $\delta^{13} \mathrm{C}$ values to calculate the $\mathrm{C}_{-}$con and the carbon preference by SIA, which was used to represent the feeding preference of A. japonicus. Previous feeding preference studies of sea cucumbers have relied on the mass budget parameters (Zhou et al. 2006, Guo et al. 2011, Song et al. 2017). In order to make the 2 approaches comparable, the carbon amounts, replacing the total matter masses, of diet ingredients, feces, and sea cucumbers were adopted to modify the mass budget parameters in this research, i.e. the carbon budget approach. It should be particularly emphasized that the C_con cannot directly reveal the carbon preferences of sea cucumber, because the total carbon amounts of different ingredients in the same diet were unequal. Therefore, it is necessary to introduce a new index, combing the C_con and carbon content information, to compare the feeding preferences of A. japonicus to ingredient carbon in the same quantity.

Within the process of sea cucumber digestion and nutrient absorption, the carbon isotope value shift from diet ingredients to the animal is attributed to carbon fractionation, i.e. the ratio redistribution of ${ }^{12} \mathrm{C}$ and ${ }^{13} \mathrm{C}$ between carbon absorbed and remaining led by the reaction velocity difference of the 2 carbon isotopes. At the start of the digestion period of a certain diet ingredient, the ratio of ${ }^{12} \mathrm{C}$ and ${ }^{13} \mathrm{C}$ is at its highest because the fractionation effect drives the initial ${ }^{12} \mathrm{C}$ and ${ }^{13} \mathrm{C}$ ratio of food digested at a higher rate than in any of the following periods. Therefore, it is possible to determine carbon isotope value shifts during digestion using the carbon absorption rates of food sources (Fry 2006). The carbon isotope fractionation factor of sea cucumbers was usually defaulted to remain unchanged in determining food contributing proportions 
by carbon stable isotope analysis (Gao et al. 2011, Xia et al. 2015, Yu et al. 2015), which suggested fixed carbon absorption rates of sea cucumber. In the present study, the relatively precise C_con resolutions and fixed absorption rates of $A$. japonicus for the 3 diet ingredients were used to propose a new approach to calculate the C_con of these ingredients.

The macroalga Chaetomorpha linum, the eelgrass Zostera marina, and muddy sediment were mixed as food sources of sea cucumbers in the present study. Zostera species are widely distributed seagrasses in the near-shore waters of northern China; their meadows can produce large amounts of seagrass leaf litter and detritus (Liu et al. 2013, Zhang et al. 2015, Zhou et al. 2015, Xu et al. 2018). In recent years, with coastal water eutrophication, the explosive growth of C. linum has led to many 'green tide blooms' and has caused serious environmental problems in northern China (Han \& Liu 2014, Zhang et al. 2014). Z. marina detritus is a reported food source of $A$. japonicus (Liu et al. 2013), and our previous research has indicated that $C$. linum may be a better diet ingredient to fulfill the nutrition demands of $A$. japonicus than $Z$. marina detritus (Song et al. 2017).

In the present study, Z. marina detritus, C. linum, and muddy sediment were mixed in different dry weight proportions to manufacture 5 experimental diets. The growth, feed utilization, and energy budgets of A. japonicus fed these different diets are presented in another publication stemming from the same experiment (Song et al. 2017). In order to test the feeding preference of $A$. japonicus to these diet sources, the carbon feeding budget of various diet treatments and relative parameters, such as carbon specific growth rate $\left(\mathrm{SGR}_{\mathrm{C}}\right)$ and food carbon conversation efficiency $\left(\mathrm{FCE}_{\mathrm{C}}\right)$, were obtained by traditional carbon budget approaches. Carbon stable isotope analysis was then applied to quantify the feeding preference of sea cucumbers for the above 3 diet ingredients. Furthermore, a new index was constructed to describe sea cucumber feeding preference based on food source contribution results obtained from carbon SIA. This research can improve knowledge of the digestive capacity and nutritional requirements of a culture species.

\section{MATERIALS AND METHODS}

\section{Experimental design and implementation}

The experiment was carried out in the laboratory at the Institute of Oceanology, Chinese Academy of Sci- ences, Qingdao, PR China, from 5 December 2015 to 4 February 2016. Sea cucumbers were collected from Swan Lake, Weihai, on 19 November 2015 when the water temperature was $13.5^{\circ} \mathrm{C}$. Prior to the initiation of the experiment, sea cucumbers were acclimated for $2 \mathrm{wk}$ to allow them to adapt to the culture conditions, and Sargassum thunbergii and muddy sediment (dry weight mixed ratio of 40:60) diet was provided as feed during acclimation. The sea cucumbers were acclimated under experimental conditions for $2 \mathrm{wk}$. After 2 d of starvation, 60 Apostichopus japonicus with initial wet body weights of $10.45 \pm 0.35 \mathrm{~g}$ (mean $\pm \mathrm{SD}$ ) were randomly selected and allocated into 20 plastic tanks $(50 \times 40 \times 30 \mathrm{~cm} ; 60$ l), such that each tank contained 3 sea cucumbers. The 20 tanks were divided into 5 treatments, and each treatment included 4 tanks. The 12 A. japonicus cultured in the 4 tanks within each treatment were offered the same diets as replicates. Tank aeration was continuous, and a third of the water volume in each tank was changed daily at 09:00 h. The culture temperature, $\mathrm{pH}$, and salinity were $16 \pm 0.5^{\circ} \mathrm{C}, 7.8-8.2$, and $30-32$ psu, respectively; the dissolved oxygen was maintained above $5.0 \mathrm{mg}$ $\mathrm{l}^{-1}$, and the photoperiod was 12:12 h (light:dark) with light intensities of 200 and 0 lux, respectively. A. japonicus were fed once a day at 10:00 h, and dietary intake was monitored to ensure that the experimental animals always had an excess of food available. The experiment was carried out for $60 \mathrm{~d}$ when the sea cucumbers completed the carbon isotope turnover after diet-switching (Sun et al. 2012).

\section{Formulation of diets}

Five mixed diet treatments were used in this experiment. All diets contained a fixed amount of muddy sediment (60\% in dry weight), which is an essential food source of sea cucumbers in their natural environment (Slater \& Jeffs 2010). The diets also contained different proportions of Zostera marina detritus and Chaetomorpha linum (Table 1, data presented in Song et al. 2017).

Fresh $C$. linum used in this experiment was collected from Swan Lake $\left(37^{\circ} 21^{\prime} N, 122^{\circ} 34^{\prime}\right.$ E), Shandong, China. Z. marina detritus was the fallen and withered autumn leaves collected from the seashore of Swan Lake. Muddy sediment was collected from the surface of non-vegetated seafloor in the coastal area of Laizhou Bay, northern China. Diet components were dried, ground, and sieved through a $0.08 \mathrm{~mm}$ mesh, and the powders obtained were mixed according to treatment proportions. 
Table 1. Ingredient proportion (\%) in dry weight of the 5 experimental diets

\begin{tabular}{|cccc|}
\hline & $\begin{array}{c}\text { Chaetomorpha } \\
\text { linum }\end{array}$ & $\begin{array}{c}\text { Zostera } \\
\text { marina }\end{array}$ & $\begin{array}{c}\text { Muddy } \\
\text { sediment }\end{array}$ \\
\hline Diet 1 & 40 & 0 & 60 \\
Diet 2 & 30 & 10 & 60 \\
Diet 3 & 20 & 20 & 60 \\
Diet 4 & 10 & 30 & 60 \\
Diet 5 & 0 & 40 & 60 \\
\hline
\end{tabular}

\section{Experimental sampling and measurement}

The wet and dry weights of a further 10 sea cucumbers of the same size as the experimental animals were measured to estimate the initial water content of the experimental animals; accordingly, the initial dry weights of the experimental $A$. japonicus were calculated. Sea cucumber feces and residual food was removed and collected by siphoning the bottom of the experimental tanks once daily (at 08:00 h), and dried at $60^{\circ} \mathrm{C}$ for $36 \mathrm{~h}$ to a constant weight for further analysis. At the end of experiment, the sea cucumbers were weighed and dissected after a final starvation period of $2 \mathrm{~d}$ to ensure complete emptying of the intestine. Residual food, sea cucumbers, and feces from each container were gathered separately. All collected samples were dried at $60^{\circ} \mathrm{C}$ for $36 \mathrm{~h}$ to obtain their dry weights, and then ground to fine powders.

The carbon contents and stable isotope ratios of feed ingredients, feces, and sea cucumbers were determined using an elemental analyzer (PE2400 Series II, PerkinElmer) coupled with an isotope ratio mass spectrometer (IRMS, Thermo Fisher Scientific; MAT 253). After acidification treatment to remove inorganic carbon, sample powders were ignited at $950^{\circ} \mathrm{C}$, and organic carbon was transformed to $\mathrm{CO}_{2}$, which was measured as carbon content by the thermal conductivity detector in the elemental analyzer. The ratio of ${ }^{13} \mathrm{C}:{ }^{12} \mathrm{C}$ in $\mathrm{CO}_{2}$ was then measured by the IRMS. Results of isotope ratios were expressed in standard $\delta$ unit notation, as follows:

$$
\delta^{13} \mathrm{C}=\left(R_{\text {sample }} / R_{\text {standard }}-1\right) \times 1000 \%
$$

where $R$ is the ${ }^{13} \mathrm{C}:{ }^{12} \mathrm{C}$ ratio. Values are reported relative to the Vienna Pee Dee Belemnite standard. A laboratory working standard (glycine) was run for every 10 samples. Analytical precision was $\pm 0.1 \%$. Since the proportion of muddy sediment was fixed $(60 \%)$ and its carbon content was below one-tenth that of the other ingredients, the differences in diet $\delta^{13} \mathrm{C}$ values were determined by the ratios of $C$. linum and Z. marina.

\section{Carbon feeding budget determination}

Based on the determination of carbon contents and dry weights of dietary ingredients, feces, and sea cucumbers (see above), we calculated carbon consumed $\left(\mathrm{C}_{\mathrm{C}}\right.$, mg ind. $\left.{ }^{-1} \mathrm{~d}^{-1}\right)$, feces carbon $\left(\mathrm{F}_{\mathrm{C}}, \mathrm{mg}\right.$ ind. ${ }^{-1}$ $\left.\mathrm{d}^{-1}\right)$, and carbon absorbed $\left(\mathrm{Ab}_{\mathrm{C}}, \mathrm{mg}\right.$ ind. ${ }^{-1} \mathrm{~d}^{-1}, \mathrm{Ab}_{\mathrm{C}}=$ $\left.\mathrm{C}_{\mathrm{C}}-\mathrm{F}_{\mathrm{C}}\right)$, as well as the initial carbon $\left(\mathrm{C}_{1}, \mathrm{mg}\right.$ ind. $^{-1}$ $\left.\mathrm{d}^{-1}\right)$ and final carbon weights $\left(\mathrm{C}_{2}, \mathrm{mg}\right.$ ind.$\left.^{-1} \mathrm{~d}^{-1}\right)$ of sea cucumbers in each plastic container. Thus the carbon growth in weight $\left(\mathrm{G}_{\mathrm{C}}\right.$, mg ind. $\left.{ }^{-1} \mathrm{~d}^{-1}\right)$ was $\mathrm{C}_{2}-\mathrm{C}_{1}$.

The $\operatorname{SGR}_{\mathrm{C}}\left(\% \mathrm{~d}^{-1}\right)$ and $\mathrm{FCE}_{\mathrm{C}}(\%)$ of sea cucumber samples were calculated according to the following formulas (Xia et al. 2012):

$$
\begin{aligned}
& \operatorname{SGR}_{\mathrm{C}}=100\left(\ln \mathrm{C}_{2}-\ln \mathrm{C}_{1}\right) \mathrm{T}^{-1} \\
& \mathrm{FCE}_{\mathrm{C}}=100\left(\mathrm{C}_{2}-\mathrm{C}_{1}\right) / \mathrm{C}_{\mathrm{C}}
\end{aligned}
$$

where $\mathrm{T}$ is the duration time of the experiment.

\section{Stable isotope analysis and determination of $C_{-}$con}

The stable isotope mixing model Stable Isotope Analysis in R (SIAR; Parnell et al. 2008) was applied to calculate C_con (\%) of feed ingredients in different diets. Average fractionation effects of $1 \%$ for carbon isotopes were used to correct stable isotope shifts for each tropic level (Peterson \& Fry 1987, Sun et al. 2013).

Since diets 1 and 5 were composed of only 2 sources (Table 1), the precision of their carbon contribution proportion resolutions through carbon isotope values could be assured. However, for diets 2 to 4, accurate resolutions could not be obtained from the probability distribution results of the SIAR mixed model. In these cases, 3 unknowns were being calculated from 2 equations, and the common problems in the calculation of C_con of 3 sources to 1 consumer were encountered. Therefore, an innovative approach to resolve the carbon contributions of food sources was needed. The following equations were constructed to calculate the final carbon contribution proportion resolutions:

$$
\begin{aligned}
& F_{\mathrm{na}} / F_{\mathrm{nc}}=P_{\mathrm{na}} / P_{\mathrm{nc}} \times f_{\mathrm{a}} / f_{\mathrm{c}} \\
& F_{\mathrm{nb}} / F_{\mathrm{nc}}=P_{\mathrm{nb}} / P_{\mathrm{nc}} \times f_{\mathrm{b}} / f_{\mathrm{c}} \\
& F_{\mathrm{na}}+F_{\mathrm{nb}}+F_{\mathrm{nc}}=1
\end{aligned}
$$

where $\mathrm{a}, \mathrm{b}$, and $\mathrm{c}$ represent the 3 ingredients of $C$. linum, Z. marina, and muddy sediment, respectively, and $\mathrm{n}$ is the number of diet treatments; $f_{\mathrm{a}}, f_{\mathrm{b}}$, and $f_{\mathrm{c}}$ represent the absorption rates by $A$. japonicus of $C$. linum, Z. marina, and muddy sediment, respectively; 
$F_{\text {na }}, F_{\text {nb }}$ and $F_{\text {nc }}$ represent the C_con of $C$. linum, $Z$. marina, and muddy sediment in various diet treatments, respectively; and $P_{\mathrm{na}}, P_{\mathrm{nb}}$, and $P_{\mathrm{nc}}$ represent the carbon composition percentages (C_com; \%) of C. linum, Z. marina, and muddy sediment in the 5 diets, respectively.

When the corresponding values of diets 1 and 5 were substituted into these equations, the fixed $f_{a} / f_{\mathrm{C}}$ and $f_{\mathrm{b}} / f_{\mathrm{c}}$ could be obtained from the 2 treatments, respectively. Finally, the known values of C_com of feed ingredients in the 5 diets, $f_{\mathrm{a}} / f_{\mathrm{C}}$, and $f_{\mathrm{b}} / f_{\mathrm{c}}$ were used to determine $C_{-}$con of the ingredients to sea cucumbers in diets 2 to 4 .

\section{Construction of the C_con:C_com ratio}

The ratio of C_con to carbon $C_{-}$com $\left(R_{C_{-} \text {con:C_com }}\right)$ of the feed ingredients in the 5 diets was constructed as a novel index to measure the relative preference of A. japonicus to different diet ingredients.

This index revealed a C_con of $1 \%$ carbon from a food source in mixed diets, considering the influence of the carbon content of the food source to its carbon contribution.

In order to compare the feeding preferences of $A$. japonicus for $C$. linum, $Z$. marina, and muddy sediment, we calculated $R_{\mathrm{C}_{-} \text {con:C_com }}$ for $C$. linum to $Z$. marina, muddy sediment to $C$. linum, and muddy sediment to $Z$. marina.

\section{Statistical analyses}

Prior to statistical analysis, data were examined for normality of distribution and homogeneity of variance with the Kolmogorov-Smirnov test and Levene's test, respectively. The potential differences among diet treatments were tested using 1-way analysis of variance (ANOVA) followed by Tukey's multiple comparison analysis to explore the possible differences between the 5 diet treatments at the significance level of 0.05 . Statistical analyses were conducted using R software 4.3 for Windows.

\section{RESULTS}

\section{Carbon budget}

The results (means $\pm \mathrm{SD}$ ) of the carbon budget are presented in Tables $2 \& 3 . \mathrm{C}_{\mathrm{C}}$ (in $\mathrm{mg}$ ind. ${ }^{-1} \mathrm{~d}^{-1}$ ) in diet 2 $(122.91 \pm 7.74)$ and diet $3(128.79 \pm 9.47)$ treatments exhibited significant differences from those in diet 4 $(89.30 \pm 2.77)$ and diet $5(88.84 \pm 3.17)$ treatments $(\mathrm{n}=4$, $F_{4,15}=8.97, \mathrm{p}<0.01$ ). Meanwhile, $\mathrm{F}_{\mathrm{C}}$ values (in $\mathrm{mg}$ ind. $\left.{ }^{-1} \mathrm{~d}^{-1}\right)$ of diet $1(64.97 \pm 4.71)$, diet $2(69.61 \pm 5.59)$, and diet $3(70.48 \pm 4.78)$ treatments significantly differed from those of diet $4(58.91 \pm 2.78)$ and diet 5 $(55.75 \pm 4.71)$ treatments $\left(\mathrm{n}=4, F_{4,15}=3.82, \mathrm{p}<0.05\right)$. We found significant differences in $\mathrm{G}_{C}$ and $\mathrm{SGR}_{\mathrm{C}}$ between diets 1-3 (diet 1: $225.67 \pm 23.89 \mathrm{mg}$ ind. $^{-1}$ and $1.53 \pm 0.14 \% \mathrm{~d}^{-1}$; diet $2: 239.75 \pm 39.61 \mathrm{mg}$ ind..$^{-1}$ and $1.57 \pm 0.16 \% \mathrm{~d}^{-1}$; diet 3: $219.49 \pm 27.46 \mathrm{mg}$ ind. $^{-1}$ and $1.49 \pm 0.12 \% \mathrm{~d}^{-1}$, respectively) and diets $4-5$ (diet 4 : $50.20 \pm 9.50 \mathrm{mg}$ ind. ${ }^{-1}$ and $0.48 \pm 0.08 \% \mathrm{~d}^{-1}$; diet $5:$ $27.25 \pm 4.53 \mathrm{mg}$ ind.$^{-1}$ and $0.28 \pm 0.04 \% \mathrm{~d}^{-1}$ ) treatments $\left(\mathrm{G}_{\mathrm{C}}: \mathrm{n}=4, F_{14}=16.29, \mathrm{p}<0.001 ; \mathrm{SGR}_{\mathrm{C}}: \mathrm{n}=4, F_{4,15}=\right.$ $30.1, \mathrm{p}<0.001) . \mathrm{FCE}_{\mathrm{C}}$ in diet $1(3.53 \pm 0.38 \%)$, diet 2 $(3.21 \pm 0.34 \%)$, and diet $3(2.83 \pm 0.18 \%)$ showed significant differences from those in diet $4(0.93 \pm 0.15 \%)$ and $\operatorname{diet} 5(0.51 \pm 0.08 \%)\left(\mathrm{n}=4, F_{4,15}=30.27, \mathrm{p}<0.001\right)$.

Table 2. Carbon feeding budget parameters of sea cucumbers in 5 diet treatments (mean $\pm \mathrm{SD}, \mathrm{n}=4$ ): carbon consumption weight $(C \mathrm{C})$, carbon in feces $\left(\mathrm{F}_{\mathrm{C}}\right)$, carbon absorbed by sea cucumber $\left(A b_{C}\right)$, carbon used for growth $\left(\mathrm{G}_{\mathrm{C}}\right)$, where $A b_{C}=C_{C}-F_{C}$ and $\mathrm{G}_{\mathrm{C}}=\mathrm{C}_{1}-\mathrm{C}_{2}\left(\mathrm{C}_{1}, \mathrm{C}_{2}\right.$ are initial and final carbon weight); also shown are carbon specific growth rate (SGR $\left.\mathrm{S}_{\mathrm{C}}\right)$ and food carbon conversion efficiency $\left(\mathrm{FCE}_{\mathrm{C}}\right)$, Values with different letters in the same row are significantly different from each other (ANOVA and Tukey's multi-comparison; $\mathrm{p}<0.05$ )

\begin{tabular}{|c|c|c|c|c|c|}
\hline & Diet 1 & Diet 2 & Diet 3 & Diet 4 & Diet 5 \\
\hline $\mathrm{C}_{\mathrm{C}}\left(\mathrm{mg}\right.$ ind $\left.^{-1} \mathrm{~d}^{-1}\right)$ & $103.72 \pm 5.29^{\mathrm{ab}}$ & $122.91 \pm 7.74^{\mathrm{a}}$ & $128.79 \pm 9.47^{a}$ & $89.30 \pm 2.77^{b}$ & $88.84 \pm 3.17^{\mathrm{b}}$ \\
\hline $\mathrm{F}_{\mathrm{C}}\left(\mathrm{mg}\right.$ ind $\left.^{-1} \mathrm{~d}^{-1}\right)$ & $64.97 \pm 4.71^{\mathrm{a}}$ & $69.61 \pm 5.59^{\mathrm{a}}$ & $70.48 \pm 4.78^{\mathrm{a}}$ & $58.91 \pm 2.78^{\mathrm{b}}$ & $55.75 \pm 4.71^{\mathrm{b}}$ \\
\hline $\mathrm{Ab}_{\mathrm{C}}\left(\mathrm{mg}\right.$ ind $\left.^{-1} \mathrm{~d}^{-1}\right)$ & $38.75 \pm 4.82^{\mathrm{ab}}$ & $53.31 \pm 5.43^{\mathrm{a}}$ & $58.32 \pm 9.35^{\mathrm{a}}$ & $30.39 \pm 3.61^{b}$ & $27.87 \pm 2.59^{\mathrm{b}}$ \\
\hline Initial carbon $\left(\mathrm{C}_{1}\right)\left(\mathrm{mg}\right.$ ind. $\left.{ }^{-1}\right)$ & $149.75 \pm 4.57^{\mathrm{a}}$ & $150.26 \pm 1.15^{\mathrm{a}}$ & $151.37 \pm 4.18^{\mathrm{a}}$ & $149.50 \pm 3.34^{\mathrm{a}}$ & $149.57 \pm 0.97^{\mathrm{a}}$ \\
\hline Final carbon $\left(\mathrm{C}_{2}\right)$ (mg ind. $\left.{ }^{-1}\right)$ & $375.42 \pm 19.87^{\mathrm{a}}$ & $390.02 \pm 40.75^{\mathrm{a}}$ & $370.86 \pm 28.07^{a}$ & $199.70 \pm 11.30^{b}$ & $176.82 \pm 4.66^{\mathrm{b}}$ \\
\hline $\mathrm{G}_{\mathrm{C}}\left(\mathrm{mg}\right.$ ind $\left.^{-1}\right)$ & $225.67 \pm 23.89^{a}$ & $239.75 \pm 39.61^{\mathrm{a}}$ & $219.49 \pm 27.46^{\mathrm{a}}$ & $50.20 \pm 9.50^{\mathrm{b}}$ & $27.25 \pm 4.53^{\mathrm{b}}$ \\
\hline $\mathrm{SGR}_{\mathrm{C}}\left(\% \mathrm{~d}^{-1}\right)$ & $1.53 \pm 0.14^{\mathrm{a}}$ & $1.57 \pm 0.16^{\mathrm{a}}$ & $1.49 \pm 0.12^{\mathrm{a}}$ & $0.48 \pm 0.08^{\mathrm{b}}$ & $0.28 \pm 0.04^{\mathrm{b}}$ \\
\hline $\mathrm{FCE}_{\mathrm{C}}(\%)$ & $3.53 \pm 0.38^{\mathrm{a}}$ & $3.21 \pm 0.34^{\mathrm{a}}$ & $2.83 \pm 0.18^{\mathrm{a}}$ & $0.93 \pm 0.15^{b}$ & $0.51 \pm 0.08^{\mathrm{b}}$ \\
\hline
\end{tabular}


Table 3. Results of ANOVA for the carbon budget parameters of sea cucumbers in 5 diet treatments. Parameters are defined in Table 2

\begin{tabular}{|c|c|c|c|c|c|c|c|c|}
\hline & \multicolumn{2}{|c|}{$-\mathrm{df}=$} & \multicolumn{2}{|c|}{ SS } & \multicolumn{2}{|c|}{$\mathrm{MS}$} & \multirow[t]{2}{*}{$F$} & \multirow[t]{2}{*}{$\mathrm{p}$} \\
\hline & Diet & Residuals & Diet & Residuals & Diet & Residuals & & \\
\hline $\mathrm{C}_{\mathrm{c}}\left(\mathrm{mg}\right.$ ind..$\left.^{-1} \mathrm{~d}^{-1}\right)$ & 4 & 15 & 4170 & 1162 & 1042.5 & 116.2 & 8.97 & $<0.01$ \\
\hline $\mathrm{F}_{\mathrm{C}}\left(\mathrm{mg}\right.$ ind.$\left.^{-1} \mathrm{~d}^{-1}\right)$ & 4 & 15 & 480.5 & 314.3 & 120.12 & 31.43 & 3.82 & $<0.05$ \\
\hline $\mathrm{Ab}_{\mathrm{c}}\left(\mathrm{mg}\right.$ ind..$\left.^{-1} \mathrm{~d}^{-1}\right)$ & 4 & 15 & 2239.5 & 559.9 & 849.2 & 84.9 & 6.59 & $<0.01$ \\
\hline $\mathrm{C}_{1}\left(\mathrm{mg} \mathrm{ind}^{-1}\right)$ & 4 & 15 & 7 & 320.6 & 1.76 & 32.06 & 0.06 & 0.99 \\
\hline $\mathrm{C}_{2}\left(\mathrm{mg} \mathrm{ind}^{-1}\right)$ & 4 & 15 & 132424 & 17987 & 33106 & 1799 & 18.41 & $<0.001$ \\
\hline $\mathrm{G}_{\mathrm{c}}\left(\mathrm{mg} \mathrm{ind}^{-1}\right)$ & 4 & 15 & 131234 & 20144 & 32808 & 20144 & 16.29 & $<0.001$ \\
\hline $\operatorname{SGR}_{\mathrm{c}}\left(\% \mathrm{~d}^{-1}\right)$ & 4 & 15 & 4.84 & 0.4 & 1.21 & 0.4 & 30.1 & $<0.001$ \\
\hline $\mathrm{FCE}_{\mathrm{c}}(\%)$ & 4 & 15 & 22.95 & 1.9 & 5.74 & 0.19 & 30.27 & $<0.001$ \\
\hline
\end{tabular}

\section{Carbon stable isotope and food contribution}

The $\delta^{13} \mathrm{C}$ and organic carbon contents (means \pm $\mathrm{SD})$ of the sea cucumbers Apostichopus japonicus and food sources used in the experiment are presented in Tables $4 \& 5$. The $\delta^{13} \mathrm{C}$ values of the 3 food sources adopted in this experiment were $-25.18 \pm$ $0.18 \%$ for muddy sediment, $-16.10 \pm 0.07 \%$ for Chaetomorpha linum, and -11.16 $\pm 0.18 \%$ for Zostera marina, respectively; these values signifi- cantly differed $\left(\mathrm{n}=4, F_{2,9}=2123.28, \mathrm{p}<0.001\right)$. At the end of this experiment, $\delta^{13} \mathrm{C}$ values of the sea cucumbers fed diet $1(-16.89 \pm 0.23 \%$ o) showed no significant difference from the initial $A$. japonicus $\delta^{13} \mathrm{C}$ value $\left(-16.95 \pm 0.44 \%\right.$, whereas the $\delta^{13} \mathrm{C}$ values of $A$. japonicus fed diets 1 to 5 were significantly different from each other (diet 1: $-16.89 \pm 0.23 \%$; diet 2: $-16.29 \pm 0.05 \%$; diet $3:-15.59 \pm 0.07 \%$; diet $4:-15.32 \pm 0.14 \%$; diet $5:-14.64 \pm 0.35 \%$; $\mathrm{n}=$ $\left.4, F_{5,18}=30.55, \mathrm{p}<0.001\right)$.

The SIAR mixed model resolved C_con of different sources in the total carbon assimilated by the sea cucumbers in the 5 diet groups (Fig. 1). C_con and C_com (means \pm $\mathrm{SD}$ ) of food sources are presented in Table 6. Sea cucumbers on diet 1 used $79.03 \pm$ $3.57 \%$ carbon from $C$. linum and $20.97 \pm$ $2.43 \%$ from muddy sediment (Table 6). In diet 5, in which $C$. linum was replaced by $Z$. marina in a mixture with muddy sediment, the proportion of carbon used from muddy sediment was $33.12 \pm 3.16 \%$, and $Z$. marina only provided $66.88 \pm 3.72 \%$ carbon for sea cucumbers (Table 6).

In diet 1 to 4 treatments, C_con from $C$. linum significantly decreased from $79.03 \pm$ $3.57 \%$ to $27.06 \pm 2.64 \%\left(\mathrm{n}=4, F_{3,12}=42.16\right.$,

Table 5. Results of ANOVA for $\delta^{13} \mathrm{C}$ and carbon content of 3 ingredients, and sea cucumbers at the beginning and end of the experiment in 5 diet treatments

\begin{tabular}{|c|c|c|c|c|c|c|c|c|c|}
\hline & \multirow{2}{*}{ Groups } & \multirow{2}{*}{ Rf $-\overline{\text { Residuals }}$} & \multicolumn{2}{|c|}{$-\mathrm{SS}$} & \multicolumn{2}{|c|}{$\mathrm{MS}$} & \multirow[t]{2}{*}{$F$} & \multirow{2}{*}{$\mathrm{p}$} \\
\hline & & & & Groups & Residuals & Groups & Residuals & & \\
\hline \multirow{2}{*}{$\begin{array}{l}\text { Diet } \\
\text { ingredients }\end{array}$} & $\delta^{13} \mathrm{C}(\%)$ & 2 & 9 & 303.71 & 0.43 & 151.85 & 0.07 & 2123.3 & $<0.001$ \\
\hline & Carbon content $(\%)$ & 2 & 9 & 944.7 & 3.7 & 472.3 & 0.6 & 767.3 & $<0.001$ \\
\hline \multirow{2}{*}{$\begin{array}{l}\text { Sea } \\
\text { cucumbers }\end{array}$} & $\delta^{13} \mathrm{C}(\%)$ & 5 & 18 & 54.07 & 4.25 & 10.81 & 0.35 & 30.55 & $<0.001$ \\
\hline & Carbon content (\%) & 5 & 18 & 35.59 & 17.2 & 7.12 & 1.43 & 4.97 & $<0.05$ \\
\hline
\end{tabular}



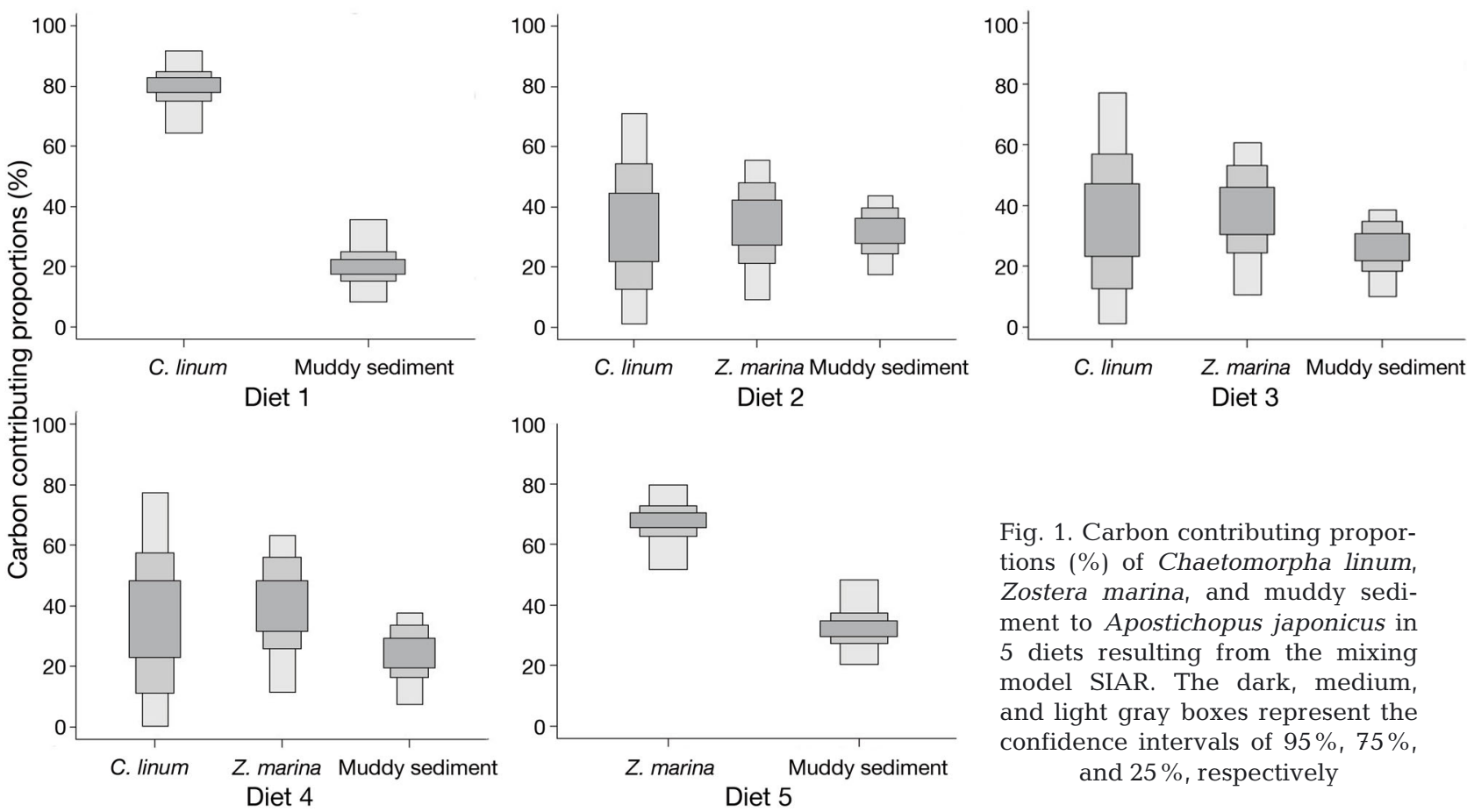

Fig. 1. Carbon contributing proportions (\%) of Chaetomorpha linum, Zostera marina, and muddy sediment to Apostichopus japonicus in 5 diets resulting from the mixing model SIAR. The dark, medium, and light gray boxes represent the confidence intervals of $95 \%, 75 \%$, and $25 \%$, respectively

Table 6. Carbon contributing proportions to sea cucumbers of the 3 ingredients in 5 experimental diets (C_con; \%), carbon composition percentages of the ingredients $\left(\mathrm{C}_{-} \mathrm{com} ; \%\right)$, and their ratios $\left(R_{\mathrm{C}_{-} \text {con:C_com }}\right)$ of the 3 ingredients in 5 diet treatments $(\mathrm{mean} \pm \mathrm{SD}, \mathrm{n}=4)$. $R_{\mathrm{C}_{-} \text {con: } \mathrm{C}_{-} \text {com }}$ is a new index for measuring the feeding preference of Apostichopus japonicus to different diet ingredients. Chaetomorpha linum and Zostera marina were not present in diets 5 and 1, respectively. C_con of the ingredients in diets 2 to 4 are calculated based on the values of C_con in diets 1 and 5, and by the equations of the absorption rate approach. The values of C_com and C_con with different letters (a, b, C, d) in the same column are significantly different from each other, and the values of $R_{\mathrm{C}_{-} \text {con:C_com }}$ with different letters (x, y, $\mathrm{z}$ ) in the same row are significantly different from each other (ANOVA and Tukey's multi-comparison; $\mathrm{p}<0.05$ )

\begin{tabular}{|c|c|c|c|c|c|c|c|c|c|}
\hline & \multicolumn{3}{|c|}{ C. linum } & \multicolumn{3}{|c|}{ Z. marina } & \multicolumn{3}{|c|}{ Muddy sediment } \\
\hline & C_com (\%) & C_con $(\%)$ & $R_{\text {C_con:C_com }}$ & C_com $(\%)$ & C_con $(\%)$ & $R_{\text {C_con:C_com }}$ & C_com (\%) & C_con $(\%)$ & $R_{\mathrm{C} \_ \text {con:C_com }}$ \\
\hline Diet 1 & $87.77 \pm 3.04^{\mathrm{a}}$ & $79.03 \pm 3.57^{\mathrm{a}}$ & $0.90 \pm 0.04^{\mathrm{Y}}$ & - & - & - & $12.23 \pm 1.04^{\mathrm{a}}$ & $20.97 \pm 2.43^{\mathrm{a}}$ & $1.71 \pm 0.18^{\mathrm{x}}$ \\
\hline Diet 2 & $61.50 \pm 1.96^{b}$ & $65.10 \pm 4.02^{\mathrm{b}}$ & $1.06 \pm 0.04^{y}$ & $27.05 \pm 0.93^{\mathrm{d}}$ & $11.78 \pm 2.06^{\mathrm{d}}$ & $0.44 \pm 0.05^{z}$ & $11.45 \pm 0.87^{a}$ & $23.12 \pm 2.65^{\mathrm{a}}$ & $2.02 \pm 0.21^{\mathrm{x}}$ \\
\hline Diet 3 & $38.48 \pm 1.14^{\mathrm{c}}$ & $48.17 \pm 3.27^{\mathrm{c}}$ & $1.25 \pm 0.05^{y}$ & $50.77 \pm 1.60^{\mathrm{c}}$ & $26.14 \pm 2.24^{\mathrm{c}}$ & $0.51 \pm 0.03^{z}$ & $10.76 \pm 0.72^{\mathrm{a}}$ & $25.69 \pm 2.83^{\mathrm{a}}$ & $2.39 \pm 0.19^{x}$ \\
\hline Diet 4 & $18.12 \pm 0.50^{\mathrm{d}}$ & $27.06 \pm 2.64^{\mathrm{d}}$ & $1.49 \pm 0.06^{\mathrm{y}}$ & $71.73 \pm 2.09^{b}$ & $44.05 \pm 2.91^{\mathrm{b}}$ & $0.61 \pm 0.03^{\mathrm{z}}$ & $10.14 \pm 0.58^{\mathrm{a}}$ & $28.89 \pm 2.72^{\mathrm{a}}$ & $2.89 \pm 0.21^{\mathrm{x}}$ \\
\hline Diet 5 & _- & - & - & $90.40 \pm 2.46^{\mathrm{a}}$ & $66.88 \pm 3.72^{\mathrm{a}}$ & $0.74 \pm 0.03^{y}$ & $9.60 \pm 0.46^{\mathrm{a}}$ & $33.12 \pm 3.16^{\mathrm{a}}$ & $3.45 \pm 0.23^{x}$ \\
\hline
\end{tabular}

Table 7. Results of ANOVA for C_com and C_con (as defined in Table 6) of ingredients in the 5 experimental diet treatments

\begin{tabular}{|c|c|c|c|c|c|c|c|c|c|}
\hline & & \multirow{2}{*}{ Diet } & \multirow{2}{*}{ df $-\overline{\text { Residuals }}$} & \multicolumn{2}{|c|}{$-\mathrm{SS}$} & \multirow{2}{*}{ Diet } & \multirow{2}{*}{ MS } & \multirow[t]{2}{*}{$F$} & \multirow{2}{*}{$\mathrm{p}$} \\
\hline & & & & Diet & Residuals & & & & \\
\hline \multirow{2}{*}{$\begin{array}{l}\text { Chaetomorpha } \\
\text { linum }\end{array}$} & C_com (\%) & 3 & 12 & 8097 & 88 & 2699 & 11 & 245.5 & $<0.001$ \\
\hline & C_con (\%) & 3 & 12 & 4526 & 286 & 1509 & 35.8 & 42.16 & $<0.001$ \\
\hline \multirow{2}{*}{$\begin{array}{l}\text { Zostera } \\
\text { marina }\end{array}$} & C_com (\%) & 3 & 12 & 6698 & 83 & 2233 & 10.4 & 215.1 & $<0.001$ \\
\hline & C_con $(\%)$ & 3 & 12 & 5104 & 192 & 1702 & 24.1 & 70.72 & $<0.001$ \\
\hline \multirow{2}{*}{$\begin{array}{l}\text { Muddy } \\
\text { sediment }\end{array}$} & C_com (\%) & 4 & 15 & 13.02 & 17.67 & 3.25 & 1.77 & 1.84 & 0.2 \\
\hline & C_con (\%) & 4 & 15 & 279.6 & 229.8 & 69.9 & 22.98 & 3.04 & 0.07 \\
\hline
\end{tabular}


Table 8. Results of ANOVA for $R_{\mathrm{C}_{-} \text {con:C_com, }}($ as defined in Table 6) of ingredients in the 5 experimental diet treatments

\begin{tabular}{|c|c|c|c|c|c|c|c|c|}
\hline & \multicolumn{2}{|c|}{$\longrightarrow \mathrm{df}-$} & \multicolumn{2}{|c|}{$-\mathrm{SS}$} & \multicolumn{2}{|c|}{$-\mathrm{MS}$} & \multirow{2}{*}{$F$} & \multirow{2}{*}{$\mathrm{p}$} \\
\hline & Ingredient & Residuals & Ingredient & Residuals & Ingredient & Residuals & & \\
\hline Diet 1 & 1 & 6 & 1 & 0.2 & 1 & 0.05 & 19.66 & $<0.05$ \\
\hline Diet 2 & 2 & 9 & 3.76 & 0.27 & 1.88 & 0.05 & 41.26 & $<0.001$ \\
\hline Diet 3 & 2 & 9 & 5.44 & 0.24 & 2.72 & 0.04 & 67.34 & $<0.001$ \\
\hline Diet 4 & 2 & 9 & 7.81 & 0.28 & 3.9 & 0.05 & 82.65 & $<0.001$ \\
\hline Diet 5 & 1 & 6 & 11.02 & 0.3 & 11.02 & 0.08 & 146.1 & $<0.001$ \\
\hline
\end{tabular}

$\mathrm{p}<0.001$; Table 7), while the contribution of $Z$. marina significantly increased from $11.78 \pm 2.06 \%$ to $44.05 \pm 2.91 \%\left(\mathrm{n}=4, F_{3,12}=70.72, \mathrm{p}<0.001 ;\right.$ Tables 6 $\& 7)$. These 2 trends were in agreement with those of the raw material and carbon content (C_com) of $C$. linum (diet 2: $61.50 \pm 1.96 \%$; diet 3: $38.48 \pm 1.14 \%$; diet $4: 18.12 \pm 0.50 \%$ ) and $Z$. marina (diet 2: $27.05 \pm$ $0.93 \%$; diet 3: $50.77 \pm 1.60 \%$; diet $4: 71.73 \pm 2.09 \%$; Table 6). There were no statistical differences in C_con of muddy sediment among the 5 diet treatments ( $\mathrm{n}=4, F_{4,15}=3.04, \mathrm{p}=0.07$; Table 7).

\section{Ratio of carbon contribution to composition}

$R_{\mathrm{C}_{-} \text {con:C_com }}$ ratios (means $\pm \mathrm{SD}$ ) of the 3 food sources are shown in Table 6 . In diet $1, R_{\mathrm{C}_{-} \text {con:C_com }}$ of $C$. linum $(0.90 \pm 0.04)$ was significantly lower than that of muddy sediment $(1.71 \pm 0.18)\left(\mathrm{n}=4, F_{1,6}=19.66, \mathrm{p}<\right.$ 0.05 ; Table 8$)$. In diet $5, R_{\mathrm{C}_{-} \text {con:C_com }}$ of $Z$. marina $(0.74 \pm 0.03)$ was also significantly lower than that of muddy sediment $(3.45 \pm 0.23)\left(\mathrm{n}=4, F_{1,6}=146.1, \mathrm{p}<\right.$ $0.001)$. For diets $2-4$, there were significant differences among the $R_{\mathrm{C}_{-} \text {con:C_com }}$ of $C$. linum, $Z$. marina, and muddy sediment, with the following trend: muddy sediment (diet 2: $2.02 \pm 0.21$; diet 3: $2.39 \pm$ 0.19 ; diet 4: $2.89 \pm 0.21)>C$. linum $(\operatorname{diet} 2: 1.06 \pm 0.04$; diet $3: 1.25 \pm 0.05$; diet $4: 1.49 \pm 0.06)>Z$. marina (diet $2: 0.44 \pm 0.05$; diet $3: 0.51 \pm 0.03$; diet $4: 0.61 \pm 0.03$ ) (diet 2: $\mathrm{n}=4, F_{2,9}=41.26, \mathrm{p}<0.001$; $\operatorname{diet} 3: \mathrm{n}=4, F_{2,9}=$ 67.34, p $<0.001$; diet $4: \mathrm{n}=4, F_{2,9}=82.65, \mathrm{p}<0.001$; Tables $6 \& 8)$. These results suggested that the feeding preferences of $A$. japonicus for the 3 experimental ingredients also followed the same order.

\section{DISCUSSION}

In this study, both carbon budget and stable isotope analysis approaches were adopted to determine the feeding preferences of sea cucumbers within the same experiment. Results indicated that aquatic plant ingredients (Chaetomorpha linum and Zostera marina) were the main carbon sources of Apostichopus japonicus in the 5 treatments, and $C$. linum was a better food source than $Z$. marina. In addition, a new potential index, i.e. the ratio of carbon contribution to composition $\left(R_{\mathrm{C}_{-} \text {con:C_com }}\right)$, was constructed to assess the feeding preferences of sea cucumbers, and results indicated that feeding preference trends of $A$. japonicus for the 3 ingredients was as follows: muddy sediment $>C$. linum $>Z$. marina in the 5 treatments. This research can improve knowledge of the digestive capacity and nutritional requirements of a culture species such as A. japonicus.

In the traditional carbon budget approach, the $\mathrm{SGR}_{\mathrm{C}}$ and $\mathrm{FCE}_{\mathrm{C}}$ were chosen to characterize this feeding preference, and conclusions were drawn based on the comparisons of these 2 parameters among different treatments. However, the results suggested that the carbon budget approach could not distinguish all preference differences of $A$. japonicus for any 2 diet treatments, such as diet 1 and diet 2 (Table 2). In the SIA approach, the distinct isotopic signatures of diet ingredients made the isotope analysis a relatively feasible approach to calculate C_con of ingredients to sea cucumbers and compare the preferences of $A$. japonicus to these diet ingredients. Compared with the carbon budget approach, the greatest advantage of SIA for determining the feeding preferences of $A$. japonicus was that with SIA, we could calculate and compare the feeding preferences for each treatment, rather than depending on the comparisons among different treatments. Another advantage of SIA to quantify the feeding preferences of $A$. japonicus was that data collection involved only measuring the carbon contents and $\delta^{13} \mathrm{C}$ values of food ingredients and tested animals; in contrast, the determination of carbon budget parameters required substantial time and labor, as feed residues and feces needed to be collected separately every day during the culture process.

The comparisons in $R_{\mathrm{C}_{-} \text {con:C_com }}$ values in each diet treatment among the 3 diet ingredients indicated the 
feeding preference of $A$. japonicus for the diet ingredients. The $R_{\mathrm{C}_{-} \text {con:C_com }}$ results clearly implied that $A$. japonicus preferred muddy sediment over the 2 aquatic plants. This result is consistent with the findings of Gao et al. (2011), who showed that A. japonicus accumulated more muddy sediment organic matter than macroalgae in diets containing a mixture of muddy sediment and macroalgae. This may be due to the fact that the highly degraded organic matter in muddy sediment is more available for sea cucumbers. Liu et al. (2009) showed that a supplement of muddy sediment in the diet of sea cucumbers enhances digestion and growth relative to pure algae powder. Despite sea cucumber preferences of carbon over muddy sediment, the addition of seaweed ingredients in diets was responsible for their markedly high carbon contents, which was almost 10 -fold that of muddy sediment and could meet the demand of A. japonicus. Along with the tendency of more $Z$. marina and less $C$. linum in the diet leading to lower $\mathrm{SGR}_{\mathrm{C}}$, the finding relating the quantitative relationship of $R_{\mathrm{C}_{-} \text {con:C_com }}$ ratios among diets supported our previous conclusion that $C$. linum is a better food source for $A$. japonicus. When discussing the application of the $R_{\mathrm{C}_{-} \text {con:C_com }}$ ratio as a standard measure of $A$. japonicus feeding preference, the meaning of $R_{\mathrm{C}_{-} \text {con:C_com }}=1$, which divides the food ingredients of the diets into 2 groups, must be further understood. For instance, in the present study, the values of $R_{\mathrm{C}_{-} \text {con:C_com }}$ of $Z$. marina were below 1 , which meant that its C_con proportions were lower than its C_com in the diet treatments. Accordingly, the diet ingredient $Z$. marina could be called a 'defective contributor' to A. japonicus in this experiment. On the other hand, muddy sediment and $C$. linum, whose $R_{\mathrm{C}_{-} \text {con:C_com }}$ ratio exceeded 1, could be called the 'surplus contributors.'

We used the isotopic mixing model SIAR to deal with the contributing proportions of 2 diet ingredients in diets 1 and 5. We made several important assumptions for that model, such as equivalent metabolic use of all carbon sources, no bacterial activity, equivalent mucus deposition on feces, and no synergistic effects among the 3 diet ingredients. In fact, the equivalent metabolic use of all carbon sources is also the foundation of the traditional carbon budget approach for determination of feeding preference. Although the impossibilities of other assumptions might unavoidably influence the validity of the isotope mixing model, the distinct isotopic signatures of diet ingredients counteracted these influences to a certain extent.

Furthermore, the absorption rate approach, rather than mixing models, was preferred to determine the contributing proportions of 3 food sources in diets
2-4. As mentioned earlier, this approach was based on the hypothesis that absorption factors of sea cucumbers with regard to the 3 ingredients remain similar even under diverse carbon ingestion and growth statuses. It is essential to note that this hypothesis, which agreed with the unchanged carbon fractionation factor $(1 \%)$ in the present experiment, is also one of the preconditions of the mixed models and the method to calculate theoretical ${ }^{13} \mathrm{C}$ values of sea cucumbers (Peterson \& Fry 1987, Hobson \& Welch 1992). Further studies investigating the variations in carbon absorption rates and stable isotope fractionation factors among A. japonicus are needed to better understand its food utilization.

In conclusion, SIA was demonstrated to be a better method for determining the feeding preference of the sea cucumber $A$. japonicus compared with the carbon budget approach. In addition, a new index, the $R_{\mathrm{C}_{-} \text {con:C_com }}$ ratio, based on carbon SIA was created to measure the feeding preference for different diet ingredients. Our work will be helpful for more efficient and accurate design and evaluation of food ingredients in the development of artificial feed for A. japonicus. Theoretically, the index $R_{\mathrm{C}_{-} \text {con:C_com }}$ is equally applicable to other experimental species for the widespread adoption of the carbon stable isotope technique in diet source preference analysis.

Acknowledgements. We thank Shilin Liu, Yuceng Bai, and Xiaoshang $\mathrm{Ru}$ for their patient and professional advice on sea cucumber culture. This research was supported by the Strategic Priority Research Program of the Chinese Academy of Sciences (XDA11020704), the NSFC-Shandong Joint Fund for Marine Science Research Centers (No. U1606404), the Aoshan Science and Technology Innovation Project (2015ASKJ02-05), the Key Research and Development Project of Shandong Province (2017GHY15111), the National Science \& Technology Basic Work Program (2015FY110600), the Creative Team Project of the Laboratory for Marine Ecology and Environmental Science, Qingdao National Laboratory for Marine Science and Technology (No. LMEESCTSP-2018-1), and the Taishan Scholars Program (Distinguished Taishan Scholars).

\section{LITERATURE CITED}

Bai Y, Zhang L, Xia S, Liu S and others (2016) Effects of dietary protein levels on the growth, energy budget, and physiological and immunological performance of green, white and purple color morphs of sea cucumber, Apostichopus japonicus. Aquaculture 450:375-382

Boutton TW, Cameron CN, Smith BN (1978) Insect herbivory on $\mathrm{C}_{3}$ and $\mathrm{C}_{4}$ grasses. Oecologia 36:21-32

Chen J (2004) Present status and prospects of sea cucumber industry in China. In: Lovatelli A, Conand C, Purcell S, Uthicke S, Hamel JF, Mercier A (eds) Advances in sea cucumber aquaculture and management. FAO, Rome, p 25-38 
Chen W, Ai Q, Mai K, Xu W, Liufu Z, Zhang W, Cai Y (2011) Effects of dietary soybean saponins on feed intake, growth performance, digestibility and intestinal structure in juvenile Japanese flounder (Paralichthys olivaceus). Aquaculture 318:95-100

Fry B (2006) Stable isotope ecology. Springer, New York, NY

*Gamboa-Delgado J, Rojas-Casas MG, Nieto-López MG, Cruz-Suárez LE (2013) Simultaneous estimation of the nutritional contribution of fish meal, soy protein isolate and corn gluten to the growth of Pacific white shrimp (Litopenaeus vannamei) using dual stable isotope analysis. Aquaculture 380-383:33-40

*Gao Q, Wang Y, Dong S, Sun Z, Wang F (2011) Absorption of different food sources by sea cucumber Apostichopus japonicus (Selenka) (Echinodermata: Holothuroidea): evidence from carbon stable isotope. Aquaculture 319: 272-276

Guo N, Dong S, Liu H (2011) Effects of several diets on the growth and body composition of Apostichopus japonicus. Yuye Kexue Jinzhan 32:122-128 (in Chinese, with English abstract)

* Güroy B, Sahin İ, Kayalı S, Mantoğlu S and others (2013) Evaluation of feed utilization and growth performance of juvenile striped catfish Pangasianodon hypophthalmus fed diets with varying inclusion levels of corn gluten meal. Aquacult Nutr 19:258-266

* Han Q, Liu D (2014) Macroalgae blooms and their effects on seagrass ecosystems. J Ocean Univ China 13:791-798

* Hobson KA, Welch HE (1992) Determination of trophic relationships within a high Arctic marine food web using $\delta^{13} \mathrm{C}$ and $\delta^{15} \mathrm{~N}$ analysis. Mar Ecol Prog Ser 84:9-18

Kelly J (2000) Stable isotopes of carbon and nitrogen in the study of avian and mammalian trophic ecology. Can J Zool 78:1-27

Li K, Xu Z, Liu Z, Gu B (2013) Stable isotope enrichment, dietary sources and trophic overlap between silver carp (Hypophthalmichthys molitrix) and bighead carp (Aristichthys nobilis). Aquaculture 402-403:8-12

Liao Y (1997) Fauna Sinica: Phylum Echinodermata Class Holothuroidea. Science Press, Beijing (in Chinese)

Liu X, Zhou Y, Yang H, Ru S (2013) Eelgrass detritus as a food source for the sea cucumber Apostichopus japonicus Selenka (Echinidermata: Holothuroidea) in coastal waters of North China: an experimental study in flowthrough systems. PLOS ONE 8:e58293

Liu Y, Dong SL, Tian XL, Wang F, Gao QF (2009) Effects of dietary sea mud and yellow soil on growth and energy budget of the sea cucumber Apostichopus japonicus (Selenka). Aquaculture 286:266-270

*McCutchan JH Jr, Lewis WM Jr, Kendall C, McGrath CC (2003) Variation in trophic shift for stable isotope ratios of carbon, nitrogen, and sulfur. Oikos 102:378-390

Newsome SD, Fogel ML, Kelly L, del Rio CM (2011) Contributions of direct incorporation from diet and microbial amino acids to protein synthesis in Nile tilapia. Funct Ecol 25:1051-1062

* Orozco ZGA, Sumbing JG, Lebata-Ramos MJH, Watanabe S (2014) Apparent digestibility coefficient of nutrients from shrimp, mussel, diatom and seaweed by juvenile Holothuria scabra Jaeger. Aquacult Res 45:1153-1163

Parnell A, Inger R, Bearhop S, Jackson AL (2008) SIAR: stable isotope analysis in R. http://cran.r-project.org/ web/packages/siar/index.html

* Peterson BJ, Fry B (1987) Stable isotopes in ecosystem studies. Annu Rev Ecol Syst 18:293-320
Phillips DL, Koch PL (2002) Incorporating concentration dependence in stable isotope mixing models. Oecologia 130:114-125

* Seo JY, Lee SM (2011) Optimum dietary protein and lipid levels for growth of juvenile sea cucumber Apostichopus japonicus. Aquacult Nutr 17:e56-e61

* Slater MJ, Jeffs AG (2010) Do sediment characteristics explain the distribution of juveniles of the depositfeeding sea cucumber Australostichopus mollis? J Sea Res 64:241-249

* Song XY, Xu Q, Zhou Y, Lin CG, Yang HS (2017) Growth, feed utilization and energy budgets of the sea cucumber Apostichopus japonicus with different diets containing the green tide macroalgae Chaetomorpha linum and the seagrass Zostera marina. Aquaculture 470:157-163

Sui X (1988) The culture and proliferation of Apostichopus japonicus. Agricultural Press of China, Beijing (in Chinese)

Sun H, Liang M, Yan J, Chen B (2004) Nutrient requirements and growth of the sea cucumber, Apostichopus japonicus. FAO Fish Tech Pap 463:327-331

Sun ZL, Gao QF, Dong SL, Shin PKS, Wang F (2012) Estimates of carbon turnover rates in the sea cucumber Apostichopus japonicus (Selenka) using stable isotope analysis: the role of metabolism and growth. Mar Ecol Prog Ser 457:101-112

* Sun Z, Gao Q, Dong S, Shin PKS, Wang F (2013) Seasonal changes in food uptake by the sea cucumber Apostichopus japonicus in a farm pond: evidence from $\mathrm{C}$ and $\mathrm{N}$ stable isotopes. J Ocean Univ China 12:160-168

* Vogel JC, Van Der Merwe NJ (1977) Isotopic evidence for early maize cultivation in New York State. Am Antiq 42: 238-242

Xia B, Wang J, Gao Q, Sun Z, Zhang L, Ma J, Liu X (2015) The nutritional contributions of dietary protein sources to tissue growth and metabolism of sea cucumber Apostichopus japonicus (Selenka): evidence from nitrogen stable isotope analysis. Aquaculture 435:237-244

Xia B, Ren Y, Wang F, Yu D, Cui G, Chen J (2017) A comparative study on growth, protein turnover and energy budget of green and white color morphs of sea cucumber Apostichopus japonicus (Selenka). Aquacult Environ Interact 9:405-414

Xia S, Yang H, Li Y, Liu S, Zhou Y, Zhang L (2012) Effects of different seaweed diets on growth, digestibility, and ammonia-nitrogen production of the sea cucumber Apostichopus japonicus (Selenka). Aquaculture 338-341: 304-308

Xu S, Wang P, Zhou Y, Zhang X and others (2018) New insights into different reproductive effort and sexual recruitment contribution between two geographic Zostera marina L. populations in temperate China. Front Plant Sci 9:15

Yang H, Hamel JF, Mercier A (2015) The sea cucumber Apostichopus japonicus: history, biology and aquaculture. Academic Press, London

Yokoyama H (2013) Growth and food source of the sea cucumber Apostichopus japonicus cultured below fish cages-potential for integrated multi-trophic aquaculture. Aquaculture 372-375:28-38

* Yu H, Gao Q, Dong S, Wen B, Hou Y, Ning L (2015) Utilization of corn meal and extruded soybean meal by sea cucumber Apostichopus japonicus (Selenka): insights from carbon stable isotope analysis. Aquaculture 435: $106-110$ 
Yu Z, Zhou Y, Yang H, Ma Y, Hu C (2014) Survival, growth, food availability and assimilation efficiency of the sea cucumber Apostichopus japonicus bottom-cultured under a fish farm in southern China. Aquaculture 426-427: 238-248

Yuan X, Yang H, Zhou Y, Mao Y, Zhang T, Liu Y (2006) The influence of diets containing dried bivalve feces and/or powdered algae on growth and energy distribution in sea cucumber Apostichopus japonicus (Selenka) (Echinodermata: Holothuroidea). Aquaculture 256:457-467

Zhang X, Zhou Y, Liu P, Wang F and others (2014) Temporal pattern in the bloom-forming macroalgae Chaetomorpha linum and Ulva pertusa in seagrass beds, Swan Lake lagoon, North China. Mar Pollut Bull 89:229-238

Zhang X, Zhou Y, Liu P, Wang F, Liu B, Liu X, Yang H (2015)

Editorial responsibility: Alejandro Buschmann,

Puerto Montt, Chile
Temporal pattern in biometrics and nutrient stoichiometry of the intertidal seagrass Zostera japonica and its adaptation to air exposure in a temperate marine lagoon (China): implications for restoration and management. Mar Pollut Bull 94:103-113

Z Zhou Y, Yang H, Liu S, Yuan X and others (2006) Feeding and growth on bivalve biodeposits by the deposit feeder Stichopus japonicus Selenka (Echinodennata: Holothuroidea) co-cultured in lantern nets. Aquaculture 256: $510-520$

Zhou Y, Liu X, Liu B, Liu P, Wang F, Zhang X, Yang H (2015) Unusual pattern in characteristics of the eelgrass Zostera marina L. in a shallow lagoon (Swan Lake), north China: implications on the importance of seagrass conservation. Aquat Bot 120:178-184

Submitted: April 5, 2017; Accepted: March 1, 2018

Proofs received from author(s): May 29, 2018 